九州大学学術情報リポジトリ

Kyushu University Institutional Repository

Some Chemical, Physical and Mineralogical Properties of Acid Sulfate Soils from the Mekong Delta in Vietnam

Tho, Huynh-tong

Laboratory of Soil Science, Faculty of Agriculture, Kyushu University

Egashira, Kazuhiko

Laboratory of Soil Science, Faculty of Agriculture, Kyushu University

https://doi.org/10.5109/22897

出版情報：九州大学大学院農学研究院紀要. 20 (3/4)，pp.151-164，1976-10. Kyushu University バージョン：

権利関係 : 


\title{
Some Chemical, Physical and Mineralogical Properties of Acid Sulfate Soils from the Mekong Delta in Vietnam
}

\author{
Huynh-tong-Tho and Kazuhiko Egashira \\ Laboratory of Soil Science, Faculty of Agriculture, \\ Kyushu University, Fukuoka, Japan
}

(Received June 14, 1976)

\begin{abstract}
Vietnam acid sulfate soils were analysed on their physico-chemical and mineralogical properties. Effects of submerging on their electrochemical and chemical changes were also investigated.

These acid sulfate soils were characterized by heavy texture, with clay and silt contents of more than $90 \%$. These soils had rather high organic matter and CEC levels but were deficient in exchangeable $\mathrm{K}$ and available $\mathrm{P}$. They were also characterized by strong acidity $(\mathrm{pH}<3.7)$. Their strong acidity was ascribed to the presence of aluminum and ferric sulfate. The clay fraction $(<2 \mu \mathrm{m})$ of these soils consisted mainly of illite and kaolinite with lesser amounts of montmorillonite, vermiculite and chlorite. The Vietnam acid sulfate soil sample showed a retarded development of soil reduction, namely, gradual decrease in $\mathrm{Eh}$ and gradual increase in $\mathrm{Fe}^{2+}$, during submergence. Its acidity did not change. Addition of starch caused a considerable increase in $\mathrm{Fe}^{2+}$, whereas addition of $\mathrm{CaCO}_{3}$ caused the precipitation of $\mathrm{Fe}^{*}+$ and $\mathrm{Al}^{\mathrm{s}+}$.
\end{abstract}

\section{INTRODUCTION}

Acid sulfate soils are soils of marine floodplains which upon drainage and aeration show a definite and severe acidification due to the oxidation of sulfides (mainly pyrites, $\mathrm{FeS}_{2}$ ) and the formation of sulfuric acid. These soils in their oxidized form show straw-yellow mottlings and streaks of basic ferric sulfate $\mathrm{KFe}_{3}\left(\mathrm{SO}_{4}\right)_{2}(\mathrm{OH})_{6}$. It is to be noted that these soils are not limited to marinc floodplains exclusively; other soils that bear $\mathrm{FeS}_{2}$ deposit in the inland may show the same characteristics. However, the acid sulfate soils outside the recent or fossil marine plains are scarce (Moormann, 1963).

Acid sulfate soils cover large areas in tropical and subtropical regions. The review of Bloomfield and Coulter (1973) gives some indications of their extent: 800,000 ha in Thailand; 2 million ha in Vietnam: 200,000 ha in Malaya; 100,000 ha in Sierra Leone; 2-3 million ha in Kalimantan.

Almost all of acid sulfate soils in Vietnam are located in the Mekong delta that is comprised of 7.5 million hectares of alluvial deposits of the Mekong river and that is typified by its extreme flatness especially in the lower part. These soils are developed in clayey alluvial sediments rich in sulfides, especially pyrites, and are often flooded by sea or fresh water in rainy season. Nearly half of these areas are so acid as to be uncultivable under the present economic condition. The less acid soils are cultivated as paddy soil but with poor produc- 
tion because of low pH per se, and toxicity of excess aluminum, iron and hydrogen sulfide.

Various investigations have been done on acid sulfate soils. The genesis and management of these soils was recently reviewed by Bloomfield and Coulter (1973). Moormann (1963) studied the acid sulfate soils of the tropics and stated that these soils which have a very high potential acidity, with pH value below 2, show an extremely low base saturation in their oxidized form. In these soils with low organic matter contents, tilth is mostly poor from the beginning. The surface layers dry up in very hard clods, whereas the deeper layers stay or become highly compact and impervious. Post and Sloane (1971) investigated the nature of clay soils from the Mekong delta, An-giang province, South Vietnam and reported that the delta soil samples consist mainly of quartz, kaolinite and illite with lesser amounts of smectite and vermiculite and traces of a large variety of soil minerals. Tanaka and Navasero (1966) studied the growth of the rice plant on acid sulfate soils from Vietnam and Malaya and concluded that the poor growth of low-land rice on acid sulfate soils is not caused by aluminum toxicity but by iron toxicity. Mai-thi-my-Nhung and Ponnamperuma (1965) studied the effects of $\mathrm{CaCO}_{3}$ and prolonged flooding on the chemical and electrochemical changes in a flooded acid sulfate soil and proposed some provisional reclamation measures.

The reclamation and improvement of acid sulfate soils are urgent need for agriculture in the tropics. For this reason, this investigation was carried out to understand the characteristics of acid sulfate soils and to consider further investigations for the satisfactory reclamation processes of these soils.

\section{PHYSICO-CHEMICAL PROPERTIES OF VIETNAM ACID SULFATE SOILS}

\section{Objective}

To characterize the physico-chemical properties of Vietnam acid sulfate soils.

\section{Materials and methods}

\section{1) Soil samples}

Acid sulfate soil samples were collected from 2 sites of a paddy field at the experimental campus of Cantho University in the Mekong delta (Fig. 1). Monthly rainfall and monthly average temperature of Cantho province are shown in Figs. 2 and 3, respectively.

Soil samples were air-dried and passed through a 2-mm sieve after grinding with a wooden pestle. They were stored in glass bottles.

\section{2) Physico-chemical analyses}

Following analytical procedures were used (Aomine and Harada, 1973) :

(1) Particle-size analysis by pipette method

(2) $\mathrm{pH}$ of $1: 2.5$ soil-water suspension, potentiometrically

(3) Exchange acidity by Daikubara method

(4) Cation exchange capacity (CEC) with the $\mathrm{Ca}\left(\mathrm{CH}_{3} \mathrm{COO}\right)_{2}$ method 


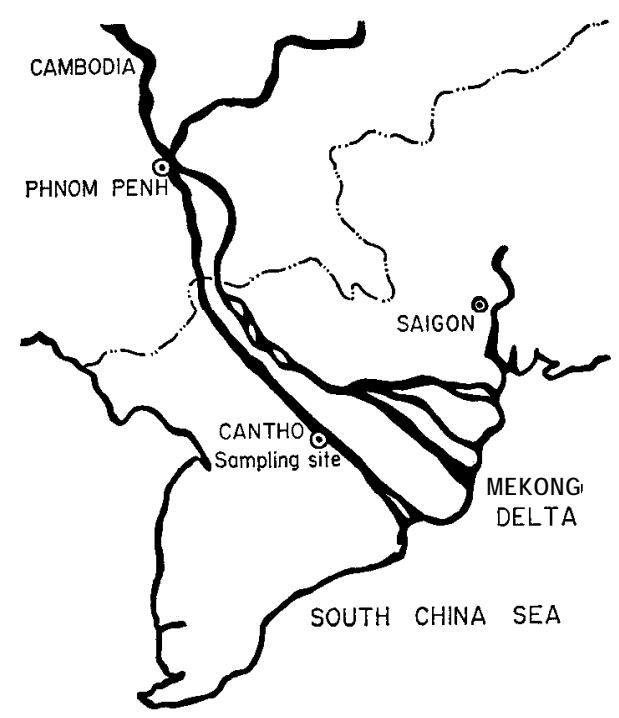

Fig. 1. Location of sampling site of Vietnam acid sulfate soils.

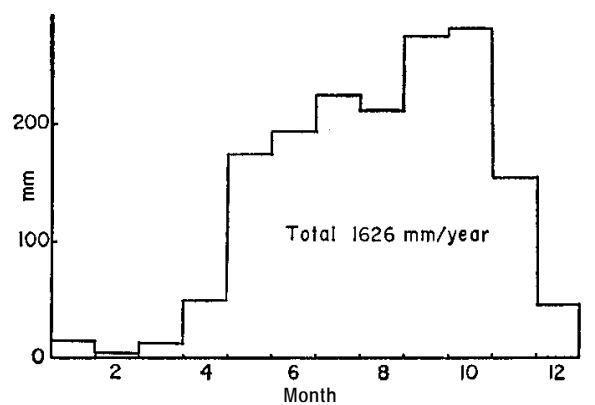

Fig. 2. Monthly rainfall in Cantho province, Mekong delta, average of 53 years. (Mekong Committee, Saigon)

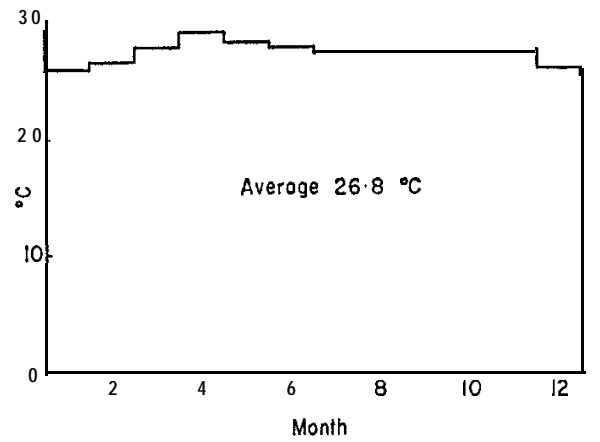

Fig. 3. Monthly temperature in Cantho province, Mekong delta, average of 1937-1940 and 1962-1970. (Directorates of meteorology in Saigon and Phnom Penh, Saigon) 
(5) Exchangeable $\mathrm{Ca}, \mathrm{Mg}, \mathrm{Na}$, and $\mathrm{K}$ in the $1 \mathrm{~N} \mathrm{NH}_{4} \mathrm{CH}_{3} \mathrm{COO}$ extract, determined by chelatometric titration with EDTA (Ca and $\mathrm{Mg}$ ) or flame photometry ( $\mathrm{Na}$ and $\mathrm{K}$ )

(6) Organic carbon by wet combustion method (Tyurin's method with minor modification) ; organic matter was calculated by multiplication of organic $\mathrm{C}$ by 1.724

(7) Total nitrogen by Kjeldahl method

(8) Available phosphorus by Bray-l method

(9) Soluble sulfate in the $\mathrm{N} \mathrm{NH}_{4} \mathrm{Cl}$ extract, determined based on the Versene chelation of the excess $\mathrm{Ba}$ remaining after $\mathrm{BaSO}_{4}$ precipitation by addition of $\mathrm{BaCl}_{2}$ (Jackson, 1958).

\section{Results and discussion}

The particle-size analysis of Vietnam acid sulfate soils is given in Table 1. The clay and silt contents were very high, and their total amounts were more than $90 \%$ for all layers. These soils were classified as heavy clay except the first layer of profile 1. Heavy texture of these soils shows their poor physical properties.

Table 1. Particle-size analysis of Vietnam acid sulfate soils.

\begin{tabular}{|c|c|c|c|c|c|}
\hline \multirow{2}{*}{ Layer } & \multirow{2}{*}{$\begin{array}{l}\text { Depth } \\
(\mathrm{cm})\end{array}$} & \multicolumn{3}{|c|}{ Content (\%) } & \multirow{2}{*}{$-\mathrm{T}$ e $x \mathrm{t}$ u r e } \\
\hline & & Sand & Silt & Clay & \\
\hline 1 & \multicolumn{4}{|c|}{ Profile 1} & \multirow{4}{*}{$\begin{array}{l}\mathrm{SiC} \\
\mathrm{HC} \\
\mathrm{HC} \\
\mathrm{HC}\end{array}$} \\
\hline 2 & $40.800-40$ & \multirow{3}{*}{$\begin{array}{l}4.62 .2 \\
1.0 \\
3.3\end{array}$} & \multirow{3}{*}{$\begin{array}{l}48.0 \\
38.7 \\
35.7 \\
45: 1\end{array}$} & \multirow{3}{*}{$\begin{array}{l}43.256 .7 \\
63.3 \\
51.6\end{array}$} & \\
\hline 3 & $80-120$ & & & & \\
\hline 4 & $120-130$ & & & & \\
\hline \multicolumn{6}{|c|}{ Profile 2} \\
\hline 1 & & & & & $\mathrm{HC}$ \\
\hline 2 & $40-80 \quad 0-40$ & 4.62 .9 & 43.151 .2 & 52.345 .9 & $\mathrm{HC}$ \\
\hline 3 & $80-120$ & 1.0 & 36.3 & 62.7 & $\mathrm{HC}$ \\
\hline 4 & $120-140$ & 2.7 & 43.9 & 53.4 & $\mathrm{HC}$ \\
\hline
\end{tabular}

SiC, Silty clay; HC, Heavy clay,

Their chemical properties are given in Table 2. Organic matter levels of these soils were not so high in the upper layers but very high in the third layer. This is the peaty layer with dark color which is always completely reduced under field condition and sometimes contains remnants of a swamp vegetation (Melaleuca leucadendron). CEC values were rather high through the profile and highest in the third layer, indicating a considerable contribution of organic matter to CEC. These soils contained large amounts of exchangeable $\mathrm{Ca}$ and $\mathrm{Mg}$. Because of the low $\mathrm{pH}$ of these soils (Table 3), considerable parts of them seem to be present as salt form, maybe as sulfates. Exchangeable $\mathrm{K}$ levels were low. The low $\mathrm{K}$ content may cause the $\mathrm{K}$ deficiency for crops. It is necessary to carry out further experiments on $\mathrm{K}$ need for these soils. Total nitrogen levels were low for all layers and $\mathrm{C} / \mathrm{N}$ ratios increased with depth. 
Table 2. Chemical properties of Vietnam acid sulfate soils.

\begin{tabular}{|c|c|c|c|c|c|c|c|c|c|c|c|}
\hline \multirow{3}{*}{ Layer } & \multirow{3}{*}{$\begin{array}{l}\text { Depth } \\
\text { (cm) }\end{array}$} & \multirow{3}{*}{$\begin{array}{c}\text { Organic } \\
\text { matter } \\
(9 \%)\end{array}$} & \multirow{3}{*}{$\begin{array}{c}\text { Total } \\
\text { nitrogen } \\
(\%)\end{array}$} & \multirow{3}{*}{$\mathrm{C} / \mathrm{N}$} & \multirow{3}{*}{$\underset{(\mathrm{me} / 100 \mathrm{~g})}{\mathrm{CEC}}$} & \multicolumn{5}{|c|}{ Exchangeable } & \multirow{3}{*}{$\underset{(\mathrm{ppm})}{\stackrel{\text { Available }}{\mathrm{P}}}$} \\
\hline & & & & & & $\mathrm{C}$ & & & $\mathrm{Na} \mathrm{K}$ & Total & \\
\hline & & & & & & \multicolumn{5}{|c|}{$(\mathrm{me} / 100 \mathrm{~g})$} & \\
\hline 1 & & 2.6 & & Profile & 1 & & & & & & \\
\hline 2 & 40.800 .40 & 4.5 & 0.160 .08 & 18.716 .3 & 31.130 .8 & 15.312 .5 & 16.016 .2 & 0.20 .7 & 0.10 .1 & 31.629 .5 & 0.9 \\
\hline 3 & $80-120$ & 15.7 & 0.35 & 26.0 & 52.5 & 29.6 & 13.0 & 0.6 & 0.1 & 43.3 & 0.1 \\
\hline 4 & $120-13$ & 7. & & 37.5 & 33. & 11.8 & 6.9 & 0.1 & 0.1 & 18.9 & 2.3 \\
\hline & & & & Profile & e 2 & & & & & & \\
\hline $\begin{array}{l}1 \\
2\end{array}$ & 40.800 .40 & 4.3 & 0.140 .07 & 17.932 .9 & 28.024 .9 & 12015.7 & 15.416 .3 & 1.21 .1 & 0.20 .5 & 28.833 .6 & $\begin{array}{l}1.1 \\
1.1\end{array}$ \\
\hline 4 & $120-140 \quad 80-120$ & $\begin{array}{l}160.56 .9 \\
16.56 .9\end{array}$ & 0.220 .08 & 43.650 .0 & 61.940 .6 & 31214.3 & 12.711 .3 & 0.10 .5 & 0.00 .1 & 44.425 .8 & 0.40 .7 \\
\hline
\end{tabular}

Table 3. Acid properties of Vietnam acid sulfate soils.

\begin{tabular}{|c|c|c|c|c|c|c|c|}
\hline \multirow{3}{*}{ Layer } & \multirow{3}{*}{$\begin{array}{l}\text { Depth } \\
\text { (cm) }\end{array}$} & \multirow{3}{*}{$\begin{array}{c}\mathrm{pH} \\
\left(\mathrm{H}_{2} \mathrm{O}\right)\end{array}$} & \multirow{3}{*}{$\begin{array}{c}\text { Exchange } \\
\text { acidity } \\
\left(y_{1}\right)\end{array}$} & \multicolumn{3}{|c|}{$\begin{array}{l}\text { Contribution to } \\
\text { exchange acidity }\end{array}$} & \multirow{3}{*}{$\begin{array}{c}\text { Soluble } \\
\mathrm{SO}_{4}^{2-} \\
(\mathrm{me} / 100 \mathrm{~g})\end{array}$} \\
\hline & & & & $\mathrm{H}^{+}$ & $\mathrm{Al}^{3+}$ & $\mathrm{Fe}^{3+}$ & \\
\hline & & & & & (\%) & & \\
\hline \multirow{4}{*}{$\begin{array}{l}1 \\
2 \\
3 \\
4\end{array}$} & & & Profile & $1_{33}$ & 65 & & \\
\hline & 40.800 .40 & $\begin{array}{l}3.0 \\
3.4\end{array}$ & $\begin{array}{r}68 \\
48\end{array}$ & $\begin{array}{l}49 \\
20\end{array}$ & 51 & $\begin{array}{l}2 \\
0\end{array}$ & $\begin{array}{l}40 \\
31\end{array}$ \\
\hline & $120-130 \quad 80-120$ & $\begin{array}{l}3.1 \\
2.7\end{array}$ & 32183 & 26 & 7817 & 577 & 8858 \\
\hline & & & Profile & ${ }^{9} 64$ & & 4 & \\
\hline \multirow{2}{*}{$\begin{array}{l}1 \\
2 \\
3 \\
4\end{array}$} & 40.800 .40 & 3.7 & 242 & 100 & 320 & 0 & 26 \\
\hline & $120-140 \quad 80-120$ & $\begin{array}{r}-5.58 \\
2.52 .8\end{array}$ & $\begin{array}{r}88 \\
256\end{array}$ & 239 & $\begin{array}{l}70 \\
36\end{array}$ & $\begin{array}{r}7 \\
55\end{array}$ & $\begin{array}{l}63 \\
89\end{array}$ \\
\hline
\end{tabular}

Available phosphorus levels were very low. This is probably ascribed to the fixation of phosphorus under forms of iron and aluminum phosphates.

Acid sulfate soils are characterized by strong acidity (usually $\mathrm{pH}<4$ ). These soil samples also had low $\mathrm{pH}(<3.7)$ and high exchange acidity $(>24)$ except the second layer of profile 2 (Table 3 ). The acidity was weakest in the second layer and increased'with depth. The contribution of $\mathrm{H}^{+}, \mathrm{Al}^{3+}$ and $\mathrm{Fe}^{3+}$ to the exchange acidity varied with layers. The contribution of $\mathrm{Al}^{3+}$ and $\mathrm{H}^{+}$ was great in the upper three layers, whereas that of $\mathrm{Fe}^{3+}$ was great in the fourth layer with the greatest acidity. The soil samples also contained very large amounts of soluble $\mathrm{SO}_{4}{ }^{2-}$ and their amounts varied proportionally to the acidity. This indicates that the presence of aluminum and ferric sulfates is a main cause of the strong acidity of acid sulfate soils (Mai-thi-my-Nhung and Ponnamperuma, 1966; Moormann, 1963).

From the above experimental results, these acid sulfate soils are characterized by heavy texture, deficiency in available $\mathrm{K}$ and $\mathrm{P}$, and strong acidity. 
These characteristics have been generally detected by many researchers for acid sulfate soils (Bloomfield and Coulter, 1973; Tanaka and Navasero, 1966; Cate and Sukhai, 1964 ; Moormann, 1963; Pham-huu-Anh et al., 1961) and would have serious effects on crop production.

\section{CLAY MINERALOGICAL PROPERTIES OF VIETNAM ACID SULFATE SOILS}

\section{Objective}

To investigate the clay mineral composition of Vietnam acid sulfate soils.

\section{Materials and methods}

Clay fractions $(<2 \mu \mathrm{m})$ were separated from the soil samples and their mineral composition was determined with deferrated and parallel-oriented specimens by x-ray diffraction method (Wada, 1966).

\section{Results and discussion}

The x-ray diffraction patterns of the clay fractions were generally similar for all layers of both profiles. Therefore, the diffraction patterns of the first layer of profile 1 are presented in Fig. 4 to represent the clay mineral composition which appears to be typical for soils in the Mekong delta.

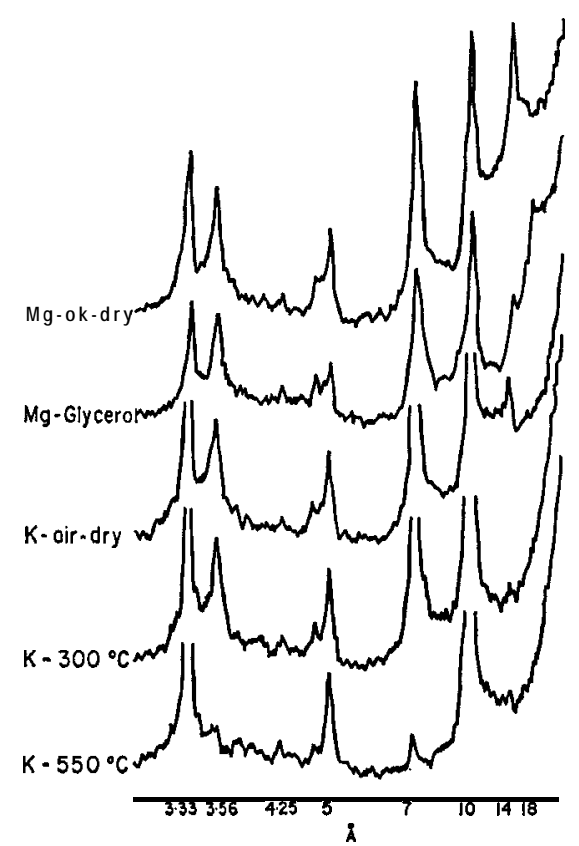

Fig. 4. X-ray diffraction patterns of the clay fraction of the first layer of profile 1 .

Illite, identified by the $10 \mathrm{~A}, 5 \AA$ and $3.3 \AA$ peaks in the Mg-saturated, air-dried and in all other specimens, existed in the most abundant amounts. In 
addition to illite, an abundance of well-crystallized kaolinite was indicated by the very strong sharp peaks at $7.1 \AA$ and $3.56 \mathrm{~A}$ whose intensities were remarkably reduced upon heating to $550^{\circ} \mathrm{C}$. There were minor amounts of montmorillonite identified by the $18 \AA$ peak in the Mg-saturated, glycerol-solvated specimen; vermiculite by the enhanced $10 \AA$ peak in the K-saturated, air-dried one; chlorite by the $14 \AA$ peak persisted after heating at $550^{\circ} \mathrm{C}$. Intergrade of chlorite-montmorillonite or chlorite-vermiculite was suggested by the $14 \AA$ peak for the K-saturated, air-dried specimen and by the reduction of its intensity after heating at $300^{\circ} \mathrm{C}$.

Quartz, identified by the $4.25 \AA$ and $3.33 \AA$ peaks, was present in small amounts for all layers. Estimated clay mineral contents of these soils are given in Table 4.

Table 4. Estimated clay mineral contents of Vietnam acid sulfate soils,

\begin{tabular}{|c|c|c|c|c|c|c|c|}
\hline \multirow{2}{*}{ Layer } & \multirow{2}{*}{$\begin{array}{l}\text { Depth } \\
\text { (cm) }\end{array}$} & It & $\mathrm{Kt}$ & $\mathrm{Mt}$ & Vt & $\mathrm{Ch}$ & Q \\
\hline & & \multicolumn{6}{|c|}{$(\%)$} \\
\hline \multicolumn{8}{|c|}{ Profile } \\
\hline $\begin{array}{l}1 \\
2 \\
3 \\
4\end{array}$ & $\begin{array}{c}0-40 \\
40-80 \\
120-130 \quad 80-120\end{array}$ & $\begin{array}{l}32 \\
31 \\
28 \\
34\end{array}$ & $\begin{array}{l}32 \\
36 \\
31 \\
38\end{array}$ & $\begin{array}{l}12 \\
13 \\
31 \\
13^{*}\end{array}$ & $\begin{array}{c}17 \\
14 \\
7 \\
11 *\end{array}$ & $\begin{array}{l}7 \\
6 \\
3 \\
4\end{array}$ & $\begin{array}{l}\mathrm{P} \\
\mathrm{P} \\
\mathrm{P} \\
\mathrm{P}\end{array}$ \\
\hline \multicolumn{8}{|c|}{ Profile 2} \\
\hline $\begin{array}{l}1 \\
2 \\
3 \\
4\end{array}$ & $\begin{array}{r}0-40 \\
40-80\end{array}$ & $\begin{array}{l}28 \\
35 \\
27 \\
22\end{array}$ & $\begin{array}{l}38 \\
40 \\
37 \\
36\end{array}$ & $\begin{array}{l}14 \\
10 \\
11^{*} \\
16^{*}\end{array}$ & $\begin{array}{c}8 \\
5 \\
10^{*} \\
17^{*}\end{array}$ & $\begin{array}{l}10 \\
159\end{array}$ & $\begin{array}{l}\mathrm{P} \\
\mathrm{P}\end{array}$ \\
\hline
\end{tabular}

It, illite; Kt, kaolinite; Mt, montmorillonite; Vt, vermiculite; Ch, chlorite; Qr, quartz;

$\mathrm{P}$, present; * intergrade.

The clay mineral composition of these soils appears to be almost the same as that of acid sulfate soils in An-giang province of South Vietnam (Post and Sloane, 1971) and of some acid sulfate soils on the Guinea coast (Horn and Chapman, 1968). Their clay fractions consist mainly of illite and kaolinite with lesser amounts of montmorillonite, vermiculite and chlorite.

\section{EFFECTS OF SUBMERGING ON ELECTROCHEMICAL AND CHEMICAL CHANGES OF A VIETNAM ACID SULFATE SOIL}

\section{Objective}

To study the effects of submerging on the electrochemical (pH and Eh) and chemical $\left(\mathrm{Fe}^{2+}\right.$ and $\left.\mathrm{Al}^{3+}\right)$ changes of Vietnam acid sulfate soil. The effects of addition of starch and $\mathrm{CaCO}_{3}$ were also investigated. The results were compared with those of a Japan paddy soil.

Materials and methods

\section{1) Soil samples}

A mixture of the first and second layers of profile 1 was used. Some of its 
properties are as follows: initial $\mathrm{pH}, 3.2$; CEC, $31 \mathrm{me} / 100 \mathrm{~g}$; organic matter, 3.5 $\%$; texture, HC. A Japan paddy soil sample was the Ap horizon of the soil collected at Kyushu Agricultural Experimental Station, with the following properties: initial $\mathrm{pH}, 5.6$; CEC, $22 \mathrm{me} / 100 \mathrm{~g}$; organic matter, $4.4 \%$; texture, CL. 2) Treatments

The treatments of Vietnam acid sulfate soil and Japan paddy soil samples are described in Tables 5 and 6 , respectively. Starch was used as organic matter source. In Japan paddy soil, $50 \mathrm{ml}$ of $0.12 \mathrm{~N} \mathrm{Al}_{2}\left(\mathrm{SO}_{4}\right)_{3}$ was used to make artificial acid sulfate soil, because this quantity of $\mathrm{Al}_{2}\left(\mathrm{SO}_{4}\right)_{3}$ decreased its $\mathrm{pH}$ to the same level as that of the Vietnam acid sulfate soil sample.

Table 5. Treatments of Vietnam acid sulfate soil sample.

\begin{tabular}{lc|ccc}
\hline & Plot & Original & + Starch & $+\mathrm{CaCO}_{3}$ \\
Treatments & & & \\
\hline Air-dried soil (g) & 25 & 25 & 25 \\
Deionized water (ml) & 50 & 50 & 50 \\
$\mathrm{CaCO}_{3}$ (g) & 0 & 0 & 0.25 \\
Starch (g) & 0 & 0.25 & 0 \\
\hline
\end{tabular}

Table 6. Treatments of Japan paddy soil sample.

\begin{tabular}{|c|c|c|c|c|}
\hline Treatments & Original & + Starch & $+\mathrm{Al}_{2}\left(\mathrm{SO}_{4}\right)_{3}$ & $\begin{array}{l}+\mathrm{Al}_{2}\left(\mathrm{SO}_{4}\right)_{3} \\
+\mathrm{Starch}\end{array}$ \\
\hline $\begin{array}{l}\text { Air-dried soil }(\mathrm{g}) \\
\text { Deionized water }(\mathrm{ml}) \\
0.12 \mathrm{~N} \mathrm{Al}_{2}\left(\mathrm{SO}_{4}\right)_{3}(\mathrm{ml}) \\
\text { Starch }(\mathrm{g})\end{array}$ & $\begin{array}{r}25 \\
50 \\
0 \\
0\end{array}$ & $\begin{array}{r}25 \\
50 \\
1\end{array}$ & $\begin{array}{r}25 \\
0 \\
50 \\
0\end{array}$ & $\begin{array}{r}25 \\
0 \\
50 \\
1\end{array}$ \\
\hline
\end{tabular}

3) Submerging of soil samples and determination of $\mathrm{pH}$, Eh, $\mathrm{Fe}^{2+}$ and $A l^{3+}$

A soil sample was kept under submerged condition in a $100 \mathrm{ml}$ centrifugal tube which was tightly packed with stopper and incubated at $25^{\circ} \mathrm{C}$. Redox potential (Eh) and $\mathrm{pH}$ of soil samples were determined every day. In the determination of $\mathrm{Eh}$, a platinum electrode was permanently seated $1 \mathrm{~cm}$ below the soil surface during incubation.

Every $5 \mathrm{~g}$ of the Vietnam acid sulfate soil samples which were kept submerged in test tubes at the same soil/water ratio was used to determine watersoluble and active $\mathrm{Fe}^{2+}$, and water-soluble and exchangeable $\mathrm{Al}^{3+}$ at every 4 days. Every $2 \mathrm{~g}$ of the Japan paddy soil samples in the same manner was used to determine active $\mathrm{Fe}^{2+}$ and exchangeable $\mathrm{Al}^{3+}$ at every 3 days. Active $\mathrm{Fe}^{2+}$ was extracted with $1 \mathrm{~N} \mathrm{NaCH}_{3} \mathrm{COO}$ of $\mathrm{pH} 2.8$ (Kumada and Asami, 1958) and exchangeable $\mathrm{Al}^{3+}$ with $\mathrm{IN} \mathrm{KCl}$. Iron and aluminum were determined by atomic absorption spectroscopy.

\section{Results and discussion}

1) $p H$

Figure 5 shows $\mathrm{pH}$ changes during submergence. In Vietnam acid sulfate soil, $\mathrm{pH}$ of the original sample was very low ( $\mathrm{pH}$ 3.2) and had almost no change 
during submergence, similar to the results of Ponnamperuma et al. (1966), in which $\mathrm{pH}$ increased at an almost imperceptible rate from 3.6 to 4.7 after 16 weeks of submergence. Addition of starch had no effect on $\mathrm{pH}$ changes. The $\mathrm{pH}$ of the soil sample treated with $\mathrm{CaCO}_{3}$ rapidly increased in the first week of submergence and then gradually decreased to about 5.8. The increase and decrease in $\mathrm{pH}$ are ascribed to the dissolution of $\mathrm{CaCO}_{3}$ and the interaction of dissolved $\mathrm{CaCO}_{3}$ and soil colloids, respectively (Nielsen, 1957).
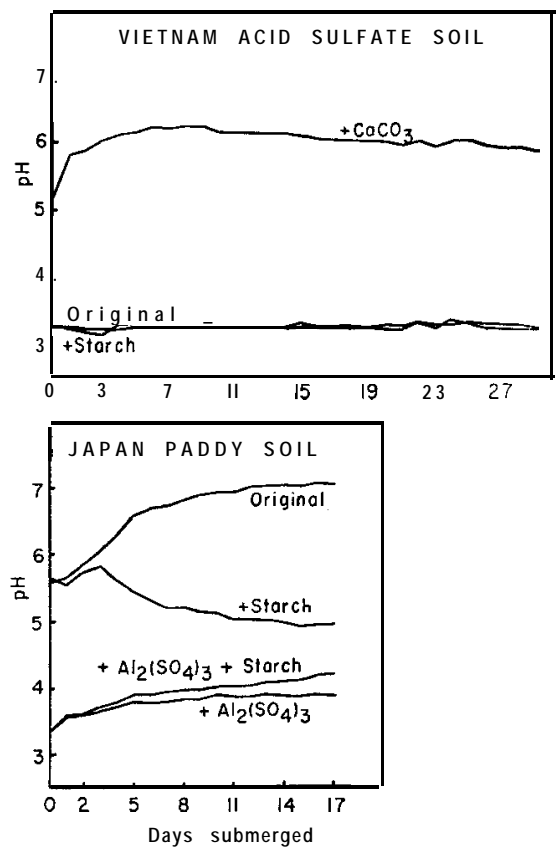

Fig. 5. Changes in $\mathrm{pH}$ during submergence.

In Japan paddy soil, $\mathrm{pH}$ of the original sample increased to about 7 during submergence, the ultimate $\mathrm{pH}$ value reached in submerged soils (Ponnamperuma, 1972). Addition of starch had a great effect on $\mathrm{pH}$ changes. The slight decrease in $\mathrm{pH}$ during the first day of submergence is probably due to the formation of carbonic acid derived from aerobic respiration of bacteria and its gradual decrease in the later periods due to the formation of organic acids.

The Japan artificial acid sulfate soil samples, made by addition of $\mathrm{Al}_{2}\left(\mathrm{SO}_{4}\right)_{3}$, showed a very gradual increase and then almost no change in $\mathrm{pH}$ during submergence, similar to that of the original and starch-treated Vietnam acid sulfate soil samples.

2) $E h$

Eh changes during submergence are shown in Fig. 6. In Vietnam acid sulfate soil, Eh of the original sample decreased gradually during submergence and was positive $(400 \mathrm{mV})$ even after one month of submergence. Addition of starch slightly decreased Eh of the system. Eh of the soil sample treated with 

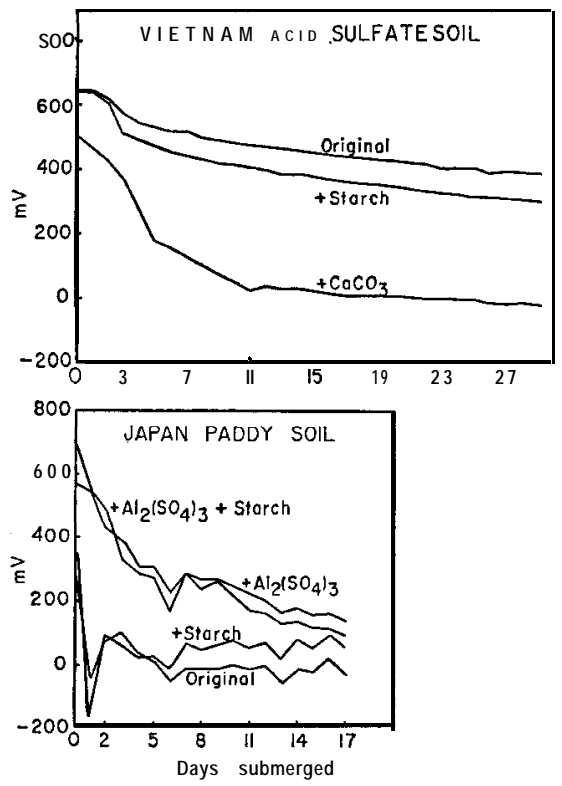

Fig. 6. Changes in Eh during submergence.

$\mathrm{CaCO}_{3}$ dropped rapidly in the early stage of submergence and appeared to get stabilized in the region of $0 \mathrm{mV}$. This rapid drop in $\mathrm{Eh}$ would be ascribed to the rapid increase in $\mathrm{pH}$ rather than the quick development of reduction.

Eh of the original and starch-treated soil samples of Japan paddy soil dropped sharply and rised again within the first two days and then fixed in the region of $0 \mathrm{mV}$. These Eh changes are a common phenomenon observed in the submergence of aerobic soils (Ponnamperuma, 1972) and the initial rapid drop in Eh has been ascribed to the release of reducing substances accompanying oxygen depletion (Ponnamperuma, 1972) or the production of hydrogen gas occurred by the decomposition of organic matter (Yamane and Sato, 1968). Addition of $\mathrm{Al}_{2}\left(\mathrm{SO}_{4}\right)_{3}$ caused gradual decrease in $\mathrm{Eh}$, similar to that of the acid sulfate soil samples.

3) $\mathrm{Fe}^{2+}$

Changes of water-soluble and active $\mathrm{Fe}^{2+}$ of Vietnam acid sulfate soil are shown in Fig. 7. Amounts of water-soluble and active $\mathrm{Fe}^{2+}$ of the original soil sample gradually increased during submergence. Addition of starch increased both forms of $\mathrm{Fe}^{2+}$. But, active $\mathrm{Fe}^{2+}$ of the soil sample treated with $\mathrm{CaCO}_{3}$ was present in considerable amounts, whereas water-soluble $\mathrm{Fe}^{2+}$ was very small. The latter is probably due to the precipitation of water-soluble $\mathrm{Fe}^{2+}$ as $\mathrm{Fe}(\mathrm{OH})_{2}$.

Changes of active $\mathrm{Fe}^{2+}$ of Japan paddy soil are shown in Fig. 8. Amounts of active $\mathrm{Fe}^{2+}$ of the original soil sample markedly increased during submergence. Addition of starch slightly increased active $\mathrm{Fe}^{2+}$. Active $\mathrm{Fe}^{2+}$ increase was retarded by addition of $\mathrm{Al}_{2}\left(\mathrm{SO}_{4}\right)_{3}$ and this retardation was more marked in the soil sample without starch. 

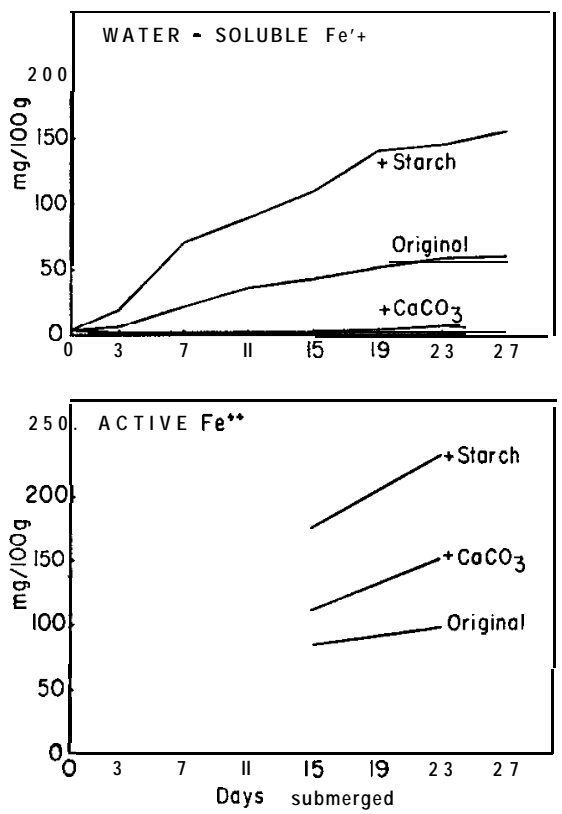

Fig. 7. Changes in $\mathrm{Fe}^{2+}$ of Vietnam acid sulfate soil during submergence.

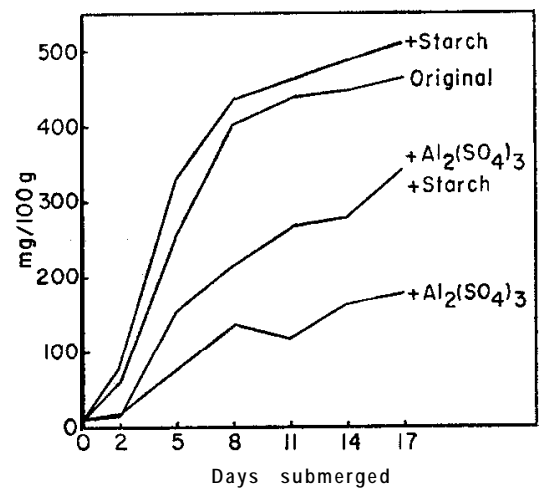

Fig. 8. Changes in active $\mathrm{Fe}^{2+}$ of Japan paddy soil during submergence.

4) $A l^{3+}$

In Vietnam acid sulfate soil (Fig. 9), water-soluble and exchangeable $\mathrm{Al}^{3+}$ of the original soil sample had no change during submergence. Addition of starch slightly decreased their amounts. Roth forms of $\mathrm{Al}^{3+}$ were disappeared by addition of $\mathrm{CaCO}_{3}$.

In Japan paddy soil, exchangeable $\mathrm{Al}^{3+}$ was not found in the original and starch-treated soil samples. Aluminum added to make the artificial acid sulfate soil $(216 \mathrm{mg} / 100 \mathrm{~g})$ was not completely extracted with $1 \mathrm{~N} \mathrm{KC1}$ and the extracted amounts gradually decreased during submergence (Fig. 10). This is maybe due 

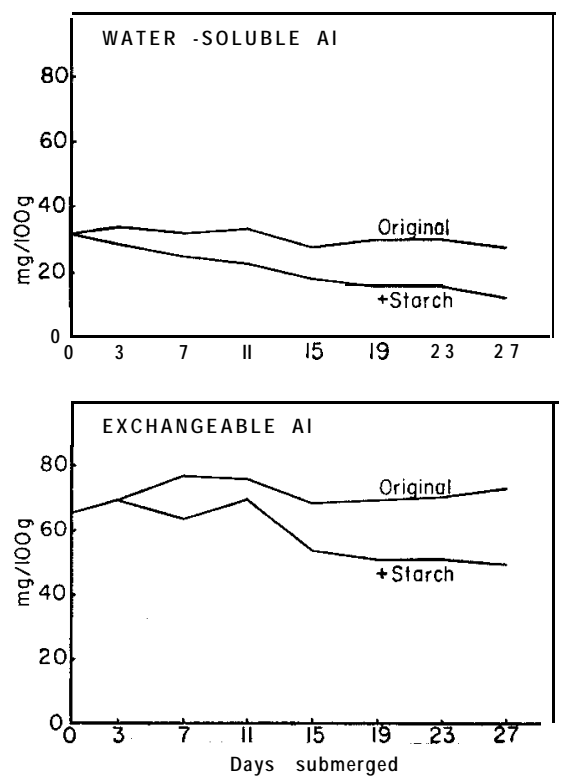

Fig. 9. Changes in $\mathrm{Al}^{3+}$ of Vietnam acid sulfate soil during submergence.

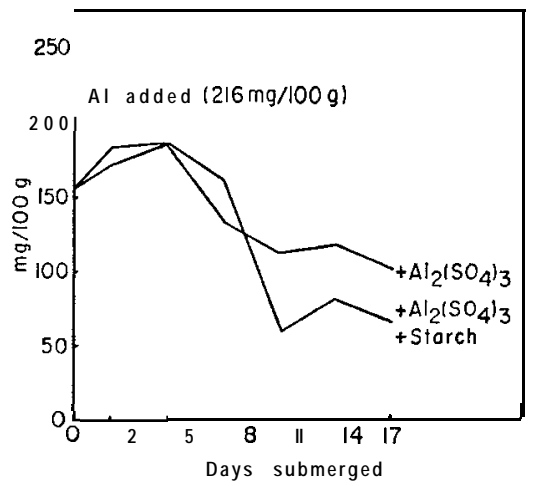

Fig. 10. Changes in exchangeable $\mathrm{Al}^{3+}$ of Japan paddy soil during submergence.

to the precipitation of $\mathrm{Al}^{3+}$ as $\mathrm{Al}(\mathrm{OH})_{3}$ or the conversion of $\mathrm{Al}^{3+}$ ions to polymerized hydroxy-Al ions.

When an aerobic soil is submerged, its Eh decreases during the first few days and gets stabilized to a value characteristic of the soil, followed by the increase of reduced substances, Comparison of the development of reduction between Vietnam acid sulfate soil and Japan paddy soil indicates that the rate of reduction is slower in Vietnam acid sulfate soil than in Japan paddy soil. This was confirmed by addition of $\mathrm{Al}_{2}\left(\mathrm{SO}_{4}\right)_{3}$ to Japan paddy soil. The slow development of reduction in Vietnam acid sulfate soil is maybe ascribed to poor 
activity of microorganisms, especially bacteria, due to its strong acidity. Addition of starch caused a quickness of the development of soil reduction and as a result a considerable increase in $\mathrm{Fe}^{2 r}$. It had almost no effect on soil acidity. Addition of $\mathrm{CaCO}_{3}$ decreased the acidity of acid sulfate soil and caused the precipitation of $\mathrm{Fe}^{2+}$ and $\mathrm{Al}^{3+}$.

\section{CONCLUSION}

From the above mentioned data, we can conclude that:

1. Vietnam acid sulfate soils are heavy clayey and extremely acid. They are deficient in nutrients such as $\mathrm{K}$ and $\mathrm{P}$.

2. Their clay fraction consists mainly of illite and kaolinite with lesser amounts of montmorillonite, vermiculite and chlorite.

3. They show a retarded development of soil reduction during submergence, as compared with Japan paddy soil.

4. Addition of $\mathrm{CaCO}_{3}$ is more effective in the decrease of the acidity and the toxicity due to iron and aluminum.

\section{REFERENCES}

Aomine, S. and T. Harada 1973 Dojo Hiryogaku Jikken Noto (in Japanese). Yokendo, Tokyo Bloomfield, C. and J. K. Coulter 1973 Genesis and management of acid sulfate soils. Advan. Agron., 25: 265-326

Cate, R. B. and A. P. Sukhai 1964 A study of aluminum in rice soils. Soil Sci., 98: 85-93

Horn, M. E. and S. L. Chapman 1968 Clay mineralogy of some acid sulfate soils on the Guinea coast. Trans. 9th Int. Congr. Soil Sci., 3: 31-40

Jackson, M. L. 1958 Soil Chemical Analysis. Prentice-Hall, Inc., Englewood Cliffs, N. J., pp. 263-266

Kumada, K. and T. Asami 1958 A new method for determining ferrous iron in paddy soils. Soil Plant Food, 3: 187-193

Mai-thi-my-Nhung and F. N. Ponnamperuma 1966 Effects of calcium carbonate, manganese dioxide, ferric hydroxide and prolonged flooding on chemical and electrochemical changes and growth of rice in a flooded acid sulfate soil. Soil Sci., 102: 29-41

Moormann, F. R. 1963 Acid sulfate soils (cat-clays) of the tropics. Soil Sci., 95: 271-275

Nielsen, K. F. 1957 Rate of change of $\mathrm{pH}$ in some acid soils due to liming. Can. J. Soil Sci., 38: 114-119

Pham-huu-Anh, F. R. Moormann and J. D. Golden 1961 Liming experiments on acid sulfate soils. In "Researches on Acid Sulfate Soils and Their Amelioration by Liming," ed. by Ministry of Rural Affairs in Vietnam, pp. 19-52

Ponnamperuma, F. N., E. Martinez and T. Loy 1966 Influence of redox potential and partial pressure of carbon dioxide on $\mathrm{pH}$ values and the suspension effect of flooded soils. Soil Sci., 101: 421-431

Ponnamperuma, F. N. 1972 The chemistry of submerged soils. Advan. Agron., 24: 29-96

Post, J. L. and R. L. Sloane 1971 The nature of clay soils from the Mekong delta, An-giang province, South Vietnam. Clays Clay Miner., 19: 21-29

Tanaka, A. and S. A. Navasero 1966 Growth of the rice plant on acid sulfate soils. Soil Sci. Plant Nutr., 12: 107-114 
Wada, K. 1966 Qualitative and quantitative determination of clay mineral (in Japanese). $J$. Sci. Soil and Manure, Japan, 37: 9-17

Yamane, I. and K. Sato 1968 Initial rapid drop of oxidation-reduction potential in submerged air-dried soils. Soil Sci. Plant Nutr., 14: 68-72 